\title{
Short-term changes in an ombrophilous atlantic forest
}

\author{
Marcela de Castro Nunes Santos TERRA ${ }^{1 *}$, José Marcio de MELLO ${ }^{1}$, Carlos Rogério de MELLO ${ }^{2}$, \\ Rubens Manoel dos SANTOS $^{1,3}$, Polyanne Aparecida COELHO ${ }^{1}$, Diego Gualberto Sales PEREIRA ${ }^{3}$, \\ Tainá Mamede Cirne SILVA ${ }^{1}$
}

\author{
${ }^{1}$ Programa de Pós-Graduação em Engenharia Florestal, Universidade Federal de Lavras, Lavras, MG, Brasil. \\ 2 Programa de Pós-Graduação em Recursos Hídricos em Sistemas Agrícolas, Universidade Federal de Lavras, Lavras, MG, Brasil. \\ ${ }^{3}$ Programa de Pós-Graduação em Botânica Aplicada, Universidade Federal de Lavras, Lavras, MG, Brasil. \\ *E-mail: marcelacns@gmail.com
}

Recebido em agosto/2017; Aceito em abril/2018.

\begin{abstract}
Characterizing and monitoring the Brazilian Atlantic Domain provide important direction for the conservation of its remnants. Short-term variations in forest composition and structure are usually lost in larger intervals between inventories and could better elucidate forest dynamics. This study aimed to analyze temporal changes in the structure, floristic composition and diversity of a tree community of an Ombrophilous Dense Forest remnant in Bocaina de Minas, Minas Gerais state, Brazil, in two short intervals. The study was conducted based on circumference at breast height $(1.3 \mathrm{~m})(\mathrm{CBH})$ data from three forest inventories $(2009,2011$, and 2012) in twelve $400 \mathrm{~m}^{2}$ permanent plots randomly distributed in the area. The results point out to a forest characterized by the increase in plant density and basal area, mainly due to the continuous local anthropogenic disturbances observed in the area, such as the presence of cattle and trails. These disturbances start early successional processes in various sectors of the forest. The altitudinal gradient leads to great environmental heterogeneity, resulting in a high species turnover, as well as high values of diversity which remained unchanged in the intervals considered. Keywords: biodiversity, forest dynamics, forest conservation.
\end{abstract}

\section{Mudanças temporais em uma floresta ombrófila atlântica em curtos intervalos de tempo}

RESUMO: A caracterização e o monitoramento do Domínio Atlântico brasileiro fornecem importante subsídio para a conservação de seus remanescentes. Variações de curto prazo na composição e estrutura de florestas são geralmente perdidas em intervalos maiores entre inventários e podem melhor elucidar a dinâmica florestal. Este estudo teve como objetivo analisar as mudanças temporais na estrutura, composição e diversidade da comunidade de árvores em uma floresta Ombrófila em Bocaina de Minas, Minas Gerais, Brasil em dois intervalos curtos. O estudo foi realizado com base em dados de circunferência à altura do peito $(1,3 \mathrm{~m})$ (CAP) de árvores medidas em três inventários florestais $\left(2009,2011\right.$ e 2012) em 12 parcelas permanentes de $400 \mathrm{~m}^{2}$ distribuídos aleatoriamente na floresta. Os resultados indicam um aumento da densidade de plantas e área basal, principalmente devido a contínuas perturbações antrópicas pontuais observadas na floresta, como a presença de gado e trilhas. Estes distúrbios desencadeiam processos iniciais de sucessão em diversos setores da floresta. O gradiente de altitude resulta em elevada heterogeneidade ambiental, com alta substituição de espécies, e em alta diversidade, a qual permaneceu inalterada nos intervalos considerados.

Palavras-chave: biodiversidade, dinâmica florestal, conservação florestal.

\section{INTRODUCTION}

The Brazilian Atlantic Forest, one of the world's most diverse tropical forests with remarkable levels of diversity and endemism, has in the last five centuries been going through a history of intense fragmentation (JOLY et al., 2014). The Atlantic Forest landscape is now a mosaic of forest fragments of different shapes and sizes surrounded by open-habitat matrices such as pastures and agricultural fields (HIGUCHI et al., 2008; RIBEIRO et al., 2009; TABARELLI et al., 2010; JOLY et al., 2014).

In Southeast Brazil, the Mantiqueira Range is a mountain chain classified as a priority for biodiversity conservation of the Atlantic Forest. Mantiqueira forests have a huge importance in providing ecosystem services as they harbor headwaters and maintain water bodies (MENEZES et al., 2009; PINTO et al., 2013). Furthermore, these forests also have high species richness and diversity, notably at upper elevations (POMPEU et al., 2014). Nevertheless, just like the rest of the Atlantic Domain, Mantiqueira is currently highly threatened. It is especially threatened by the consolidation and expansion of agricultural and urban frontiers, as well as mineral extraction (TABARELLI et al., 2010).

Altitudinal gradients on the Mantiqueira slopes are highly heterogeneous environments and have a direct impact upon the vegetation they host (POMPEU et al., 2014). Most of the available studies in this region have provided important insights into the species turnover following these altitudinal gradients (PEREIRA et al., 2006a; PEREIRA et al., 2006b; VALENTE et al., 2011). Although Mantiqueira is such a peculiar and endangered area, we still know little about the floristic composition and structure of its forests. Studies regarding forest dynamics are even scarcer (OLIVEIRAFILHO et al., 2007) and usually have intervals of 4-5 years between inventories. 
The realization of successive surveys to collect temporal datasets is usually difficult and expensive (SHEIL; MAY, 1996; JUNTILLA et al., 2015), while the investigation of changes in forest structure and composition remain fundamental to the better description of tree communities. Forest dynamics studies are likely to be a key towards more realistic future scenarios and more effective conservation and management strategies (LEVIN-NIELSEN; RIESKE, 2015). Therefore, in the present study, we sought to characterize the structure, floristic composition and dynamics of the tree stratum of a forest fragment in Southeast Brazil in two short two years and one year - intervals.

\section{MATERIALS AND METHODS}

2.1. Study area and data collection

The study area is a 13.71 ha Atlantic Ombrophilous forest remnant, located in the municipality of Bocaina de Minas, Brazil (22 $07^{\prime} \mathrm{S}$ to $22^{\circ} 09^{\prime} \mathrm{S}$ and $44^{\circ} 26^{\prime} \mathrm{W}$ to $44^{\circ} 29^{\prime} \mathrm{W}$, altitudinal range of 1400-1700 $\mathrm{m}$ ). The forest fragment has a small watercourse (Figure 1). The climate was classified as Cwb of Köppen with cold, less humid winters and mild and rainy summers. The soil is moderately deep $(<1.5 \mathrm{~m})$, with granite-gneiss parent material (MENEZES et al., 2009).

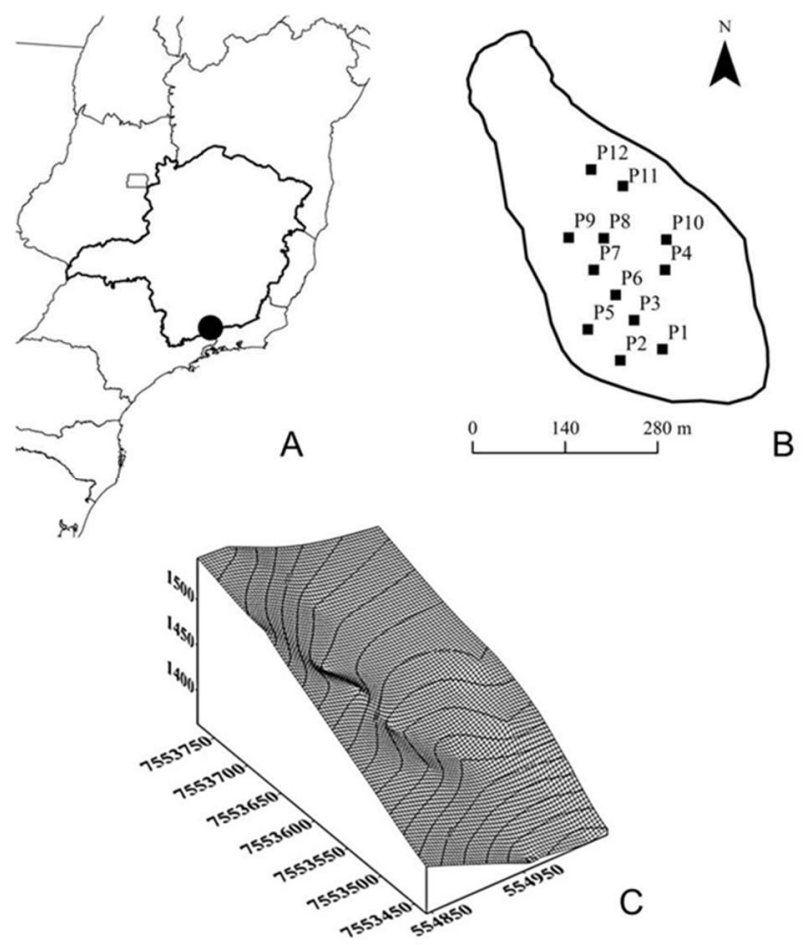

Figure 1. A. Location of the Atlantic Ombrophilous forest remnant in Bocaina de Minas, Minas Gerais state, Brazil; B. The vegetation sampling plots (P1-P12); C. Topographic representation of the area with the geographic coordinates (UTM) and isolines spaced by 10 meters (the depression in the center coincides with the watercourse in the area).

Figura 1. A. Localização do remanescente de floresta Ombrófila Atlântica em Bocaina de Minas, Minas Gerais, Brasil; B. Parcelas de amostragem da vegetação (P1-P12); C. Representação topográfica da área com as coordenadas geográficas (UTM) e isolinhas espaçadas em 10 metros (a depressão no centro coincide com o corpo d'água existente na área).

We inventoried the tree community in June 2009, by randomly laying out 12 permanent plots (P1-P12) of $400 \mathrm{~m}^{2}$ $(20 \times 20 \mathrm{~m})$. The altitudes of the plots varied between $1403 \mathrm{~m}$ and $1541 \mathrm{~m}$. In each plot, we sampled all live trees with diameter of at least $5 \mathrm{~cm}$ at $1.30 \mathrm{~m}$ above the ground $(\mathrm{CBH})$. Each individual had its $\mathrm{CBH}$ recorded and the identification of the botanical material was done by an expert. In July 2011 and July 2012, we measured the surviving and recruit trees and recorded the dead ones.

\subsection{Data analyses}

Forest Dynamics - We obtained dynamics parameters for both 2009-2011 and 2011-2012 intervals. We calculated values of mortality, recruitment, ingrowth, outgrowth rates and number of individuals and basal area turnover rates through, respectively, the mean of mortality-recruitment rates and the mean of ingrowth-outgrowth rates (OLIVEIRA-FILHO et al., 2007). We also calculated the half-life and duplication times for the number of individuals (KORNING; BALSEV, 1994; OLIVEIRA-FILHO et al., 2007). Mean annual mortality (1), recruitment (2), outgrowth (3) and ingrowth (4) rates were calculated using the follow expressions:

$$
\begin{gathered}
\mathrm{M}=\left(1-\left[\frac{\left(\mathrm{N}_{0}-\mathrm{N}_{\mathrm{m}}\right)}{\mathrm{N}_{0}}\right]^{\frac{1}{\mathrm{t}}}\right) * 100 \\
\mathrm{R}=\left(1-\left(1-\frac{\mathrm{N}_{\mathrm{r}}}{\mathrm{N}_{1}}\right)^{\frac{1}{\mathrm{t}}}\right) * 100 \\
\mathrm{O}=\left(1-\left(\frac{\mathrm{AB}_{0}-\left(\mathrm{AB}_{\mathrm{d}}+\mathrm{AB}_{\mathrm{m}}\right)}{\mathrm{AB}_{0}}\right)^{\frac{1}{\mathrm{t}}}\right) * 100 \\
\mathrm{I}=\left(1-\left(1-\left(\frac{A B_{r}+A B_{i}}{A B_{1}}\right)\right)^{\frac{1}{t}}\right) * 100
\end{gathered}
$$

where: $t$ is the time (years) between the inventories; $\mathrm{N}_{0}$ and $\mathrm{N}_{1}$ are, respectively, the initial and final number of individuals; $\mathrm{N}_{\mathrm{r}}$ and $\mathrm{N}_{\mathrm{m}}$ are, respectively, the number of recruits and dead trees; $\mathrm{AB}_{0}$ and $\mathrm{AB}_{1}$ are, respectively, the initial and final basal area; $A B_{r}$ and $A B_{m}$ are, respectively, the basal area of recruits and dead trees; and $\mathrm{AB}_{\mathrm{d}}$ and $\mathrm{AB}_{\mathrm{i}}$ are, respectively, the basal area outgrowth and ingrowth of the surviving trees (SHEIL et al., 1995; SHEIL et al., 2000).

Paired t-tests at $0.5 \%$ were used to compare absolute density, basal area and dynamics rates between the intervals.

We also examined the distribution (frequency) of individuals in diametric classes of $3 \mathrm{~cm}$ comparing the three forest inventories using Wilcoxon test 5\% (ZAR, 1984).

Floristic composition and phytosociology - In order to describe the overall structure, we calculated (absolute and relative) density, (absolute and relative) dominance, (absolute and relative) frequency and importance value (IV) for the whole tree community (MUELLER-DOMBOIS; ELLENBERG, 1974). We also estimated the Shannon-Wiener Index (H') and the Pielou Evenness (J') (KENT; COKER, 1992) for the three inventories. We compared the Shannon Index estimates through the average curve (estimated value \pm standard deviation) of 1000 randomizations of the ShannonWiener Index as a function of the number of individuals using the software Estimate S 8.0 (COLWELL, 2011).

\subsection{Gradient analyses}

We used detrended correspondence analysis (DCA) in order to assess the spatial turnover for the three inventories. The 
matrices of species per plot were built using the raw number of individuals belonging to each species in each plot. The analyses were performed using the software PC-ORD 5.10 (MCCUNE; MEFFORD, 2006).

\section{RESULTS}

\subsection{Forest Dynamics}

We sampled 1013 individual in 2009, 1063 in 2011, and 1071 in 2012. Overall, the community increased in both density and basal area in the intervals considered. The differences between mortality and recruitment were smaller in the second interval, which led to more balanced half-life and duplication times. The rates regarding basal area were higher in the second interval. The dynamics rates can be seen in Table 1. The frequency distribution of diameter displayed a reverse$\mathrm{J}$ shape for all three inventories (Figure 2) and, according to the Wilcoxon test, significant differences were detected for the 2009-2011 interval $(p=0.014)$, but not for the 2011-2012 interval $(\mathrm{p}=0.408)$.

Table 1. Parameters of the structure, dynamics and diversity of three inventories (2009, 2011 and 2012) of the Atlantic Ombrophilous forest remnant in Bocaina de Minas, Minas Gerais state, Brazil. (AD - Absolute density; BA - total basal area; $\mathrm{M}$ - mortality rate; $\mathrm{R}$ recruitment rate; $\mathrm{T}(\mathrm{N})$ - number of individuals turnover rate; $\mathrm{O}$ outgrowth rate; I - ingrowth rate; $\mathrm{T}$ (BA) - basal area turnover rate; H'- Shannon -Wiener diversity Index estimate; J' - Pielou's evenness). *Value statistically different from the previous value according to paired t-test at $0.5 \%$.

Tabela 1. Parâmetros de estrutura, dinâmica e diversidade dos três inventários florestais $(2009,2011$ e 2012) do remanescente de floresta Ombrófila Atlântica em Bocaina de Minas, Minas Gerais, Brasil. (AD - densidade absoluta; BA - área basal total; $\mathrm{M}$ - taxa de mortalidade; $\mathrm{R}$ - taxa de recrutamento; $\mathrm{T}(\mathrm{N})$ - taxa de rotatividade em número de indivíduos; $\mathrm{O}$ - taxa de perda em área basal; I - taxa de ganho em área basal; T (BA) - taxa de rotatividade em área basal; H'- estimativa do índice de Shannon -Wiener; J' - equabilidade de Pielou). *Valor estatisticamente diferente do valor anterior de acordo com o teste t pareado a $0,5 \%$.

\begin{tabular}{lllll}
\hline & Parameters & 2009 & 2011 & 2012 \\
\hline \multirow{5}{*}{ Forest } & $\mathrm{AD}-$ live trees $(/ \mathrm{ha})$ & 2110.4 & $2214.6^{*}$ & 2233.3 \\
Structure & $\mathrm{AD}-$ dead trees & - & 12.5 & $41.67^{*}$ \\
& $\mathrm{AD}-$ recruits(/ha) & - & 116.67 & $58.33^{*}$ \\
& $\mathrm{BA}-$ live trees & 22.69 & $24.99^{*}$ & $25.85^{*}$ \\
\hline \multirow{5}{*}{ Forest } & $\mathrm{M}(\%)$ & - & 0.3 & $1.88^{*}$ \\
& $\mathrm{R}(\%)$ & - & 2.67 & 2.61 \\
& $\mathrm{~T}(\mathrm{~N})(\%)$ & - & 1.48 & 2.25 \\
Dynamics & Half-life time & - & 234.1 & 37.19 \\
& Duplication time & - & 26.31 & 26.86 \\
& $\mathrm{O}(\%)$ & & 0.81 & 2.25 \\
& $\mathrm{I}(\%)$ & & 5.46 & $8.95^{*}$ \\
& $\mathrm{~T}(\mathrm{BA})(\%)$ & - & 3.13 & $5.6^{*}$ \\
\hline \multirow{5}{*}{ Diversity } & Species richness & 101 & 105 & 105 \\
& $\mathrm{H}$ ' (nats/ind) & 3.79 & 3.81 & 3.81 \\
& $\mathrm{~J}$ & 0.82 & 0.82 & 0.82 \\
\hline
\end{tabular}

\subsection{Floristic composition and phytosociology}

In 2009 we registered 101 species belonging to 64 genera and 39 botanical families. In 2011 we registered 105 species, 66 genera and 40 families, and finally, in 2012, we registered the same 105 species as in 2011. One of the few differences detected in the 2011 inventory compared to 2009 was the ingress into the sample of Aspidosperma olivaceum Müll. Arg., Symplocos insignis Brade, A., Baccharis brachylaenoides DC. and Tovomitopsis saldanhae Engl., all of them with low density (only one individual) (Table 2).

The community main species (IV) in 2009 practically maintained their hierarchical positions with a few changes in their positions in both intervals. The main five species in all inventories were Lamanonia ternata Vell., Psychotria vellosiana Benth., Myrsine umbellata Mart., Myrcia splendens (Sw.) DC. and Clethra scabra Pers. The other species also suffered some changes in their hierarchical positions, and the ingress of four species into the sample did not alter the general phytosociological structure.

We did not detect significant differences among the estimated diversity in the inventories, once there was an overlap of the standard deviation of the three diversity curves (Figure 3).

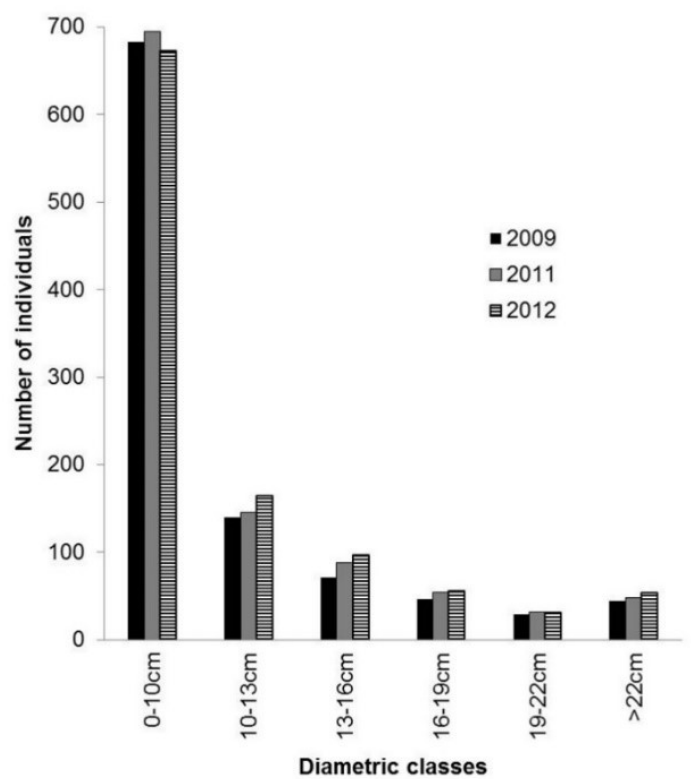

Figure 2. Observed frequencies in diameter classes in the three forest inventories (2009, 2011 and 2012) of the Atlantic Ombrophilous forest remnant in Bocaina de Minas, Minas Gerais state, Brazil. Figura 2. Frequências observadas em classes de diâmetro em três inventários florestais $(2009,2011$ e 2012) do remanescente de floresta Ombrófila Atlântica em Bocaina de Minas, Minas Gerais, Brasil.

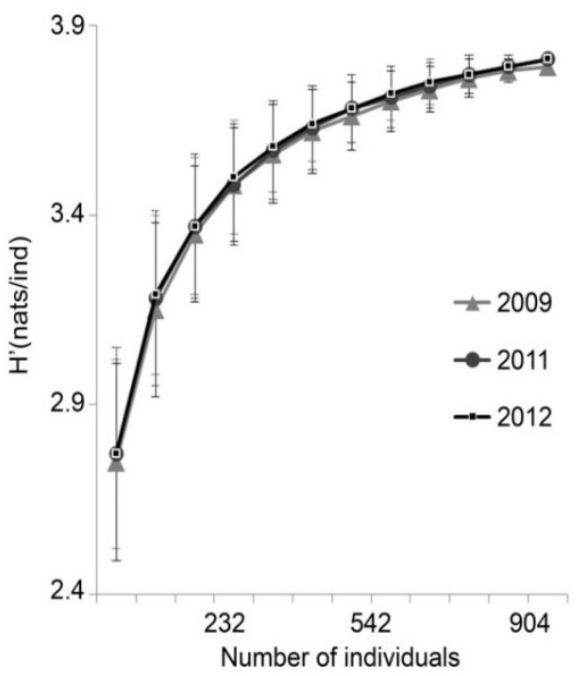

Figure 3. Average curves (estimated values \pm standard deviations) of 1000 randomizations of the Shannon-Wiener Index as a function of the number of individuals in the three forest inventories $(2009,2011$ 
and 2012) of the Atlantic Ombrophilous forest remnant in Bocaina de Minas, Minas Gerais state, Brazil.

Figura 3. Curvas medias (valores estimados \pm desvios-padrão) de 1000 randomizações do Índice de Shannon-Wiener em função do número de indivíduos em três inventários florestais $(2009,2011$ e 2012) do remanescente de floresta Ombrófila Atlântica em Bocaina de Minas, Minas Gerais, Brasil.

\subsection{Gradient analyses}

The ordination of plots via DCA for all three inventories resulted in long gradients with high species turnover in the first axis, related to the altitudinal position, and in not so long gradients in the second axis, probably reflecting the position in relation to the watercourse in the second axis (Figure 4). In 2009, the eigenvalues 1 and 2 were 0.5595 and 0.2831 respectively; in 2011, 0.5525 and 0.2784 ; and in 2012, 0.5432 and 0.2736 .
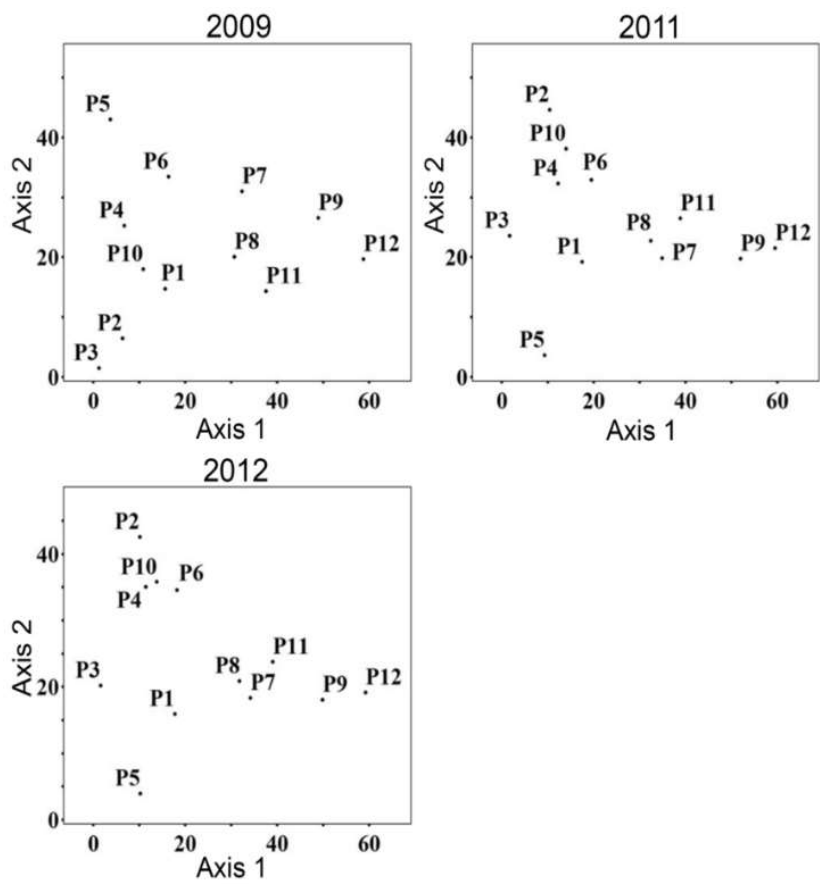

Figure 4. Diagrams of detrended correspondence analysis (DCA) showing the arrangement of plots in relation to the number of individuals of each species present in the plots of three forest inventories (2009, 2011 and 2012) of the Atlantic Ombrophilous forest remnant in Bocaina de Minas, Minas Gerais state, Brazil. Figura 4. Diagramas de análise de correspondência destendenciada (DCA) mostrando o arranjo das parcelas com base no número de indivíduos de cada espécie presente nos três inventários florestais (2009, 2011 e 2012) do remanescente de floresta Ombrófila Atlântica em Bocaina de Minas, Minas Gerais, Brasil.

\section{DISCUSSION}

Our findings show for both 2009-2011 and 2011-2012 intervals higher recruitment rates than mortality rates and higher ingrowth rates than outgrowths rates, which resulted in an increase of the liquid density and basal area. This pattern, in the first instance, is related to a process of recovering from disturbances (CHAZDON et al., 2007). In this context, the increase in number of individuals and basal area in both intervals suggests that the forest is going through structural rearrangement after some previous disturbance had an impact upon the tree community organization and biomass (CHAZDON et al., 2007; CARVALHO; FELFILI. 2011).
Several disturbances commonly cause instability in tropical forests. Natural and anthropogenic disturbances such as gaps, selective logging, trails and cattle might locally trigger early phases of the successional process normally characterized by the increase of both tree biomass and density (OLIVEIRA-FILHO et al., 2007; MACHADO; OLIVEIRAFILHO, 2010). In fact, in our study area, although there is no clear cut record for over 30 years, the continuous punctual anthropogenic disturbances caused by the cattle access to some sectors of the area and the existence and maintenance of walk trails and fences in other sectors, might have an impact on the overall dynamic rates by holding the forest in an earlier successional condition. We also have to consider a context of preterit and large-scale disturbances resulting from the fragmentation process and its immediate and late impacts, which might boost the dynamic rates in areas under the influence of edges (OLIVEIRA-FILHO et al., 2007). The effects of fragmentation and the extension of the edges are little explored and certainly affect the community dynamics, although there is some controversy in the literature regarding this topic (PHILLIPS et al., 2008).

The differences in dynamic rates found for both intervals precisely elucidate punctual fluctuations within the periods. Such short-term variations are usually lost in larges intervals once dynamic rates are impacted by the interval between the inventories (SHEIL; MAY, 1996). Although mortality and recruitment at small spatial scales can be very irregular (PHILLIPS et al., 2009; LIBERMAN et al., 1985), and in spite of the sensitivity of these rates to the interval length, the values of turnover in number of individuals we found are within previous values attributed to tropical rainforests (PHILLIPS et al., 2004). The differences we found for the diametric distribution in 2009-2011 are mainly due to the recruitment of individuals in intermediary classes of diameter, reflecting the growth of individuals sampled in the first inventory and the total increase in basal area.

Our forest showed floristic characteristics known as indicators of forests of higher altitudes in Southeast Brazil such as higher relative richness of Melastomataceae (13 species), Asteraceae (8), Lauraceae (8), Annonaceae (6), Myrtaceae (6), Sapindaceae (5), Myrsinaceae (4) and Rubiaceae (4) (NASCIMENTO et al., 2010; OLIVEIRAFILHO; FONTES, 2000). According to Pereira et al. (2006a), Melastomataceae is a very representative family in mountain Ombrophilous forests, where this family finds suitable conditions for its colonization and occupancy strategies. The mountain forest feature was enhanced by the occurrence of indicator species such as L. ternata and Symplocos celastrinea Mart. ex Miq. (OLIVEIRA-FILHO; FONTES, 2000). We observed stability in floristic composition and structure in the intervals as (1) we recorded a slight increase in species richness of low density species, and the "new" species were certainly already present in the local pool of species (but not in our plots); and (2) the community main species in terms of IV remained the same in all three inventories. These species were also found among the more important in other ombrophilous forest of Mantiqueira region (PEREIRA et al., 2006a).

The diversity index for the three inventories $(3.79,3.81$ and 3.81nats.ind ${ }^{-1}$ ), with no statistically significant changes in the intervals, can be considered high and close to the average values found in similar conditions (PEREIRA et al., 2006a). This pattern agrees with that normally obtained for tropical 
mountain forests where the declivity gradient (altitudinal gradient) causes high spatial species turnover (GENTRY, 1995; MEIRELES et al., 2008). The species turnover is confirmed by the long first axis in the DCA in all inventories. The altitudinal range (around $100 \mathrm{~m}$ ) certainly contributed to the environmental heterogeneity providing the formation of edaphic and topographic gradients, which is reflected in the species composition and structure of the forest community. Despite the remarkable climate-driven variations in larger scales as a consequence of latitude and distance from the ocean (OLIVEIRA-FILHO; FONTES, 2000), in small local-scales, as is the case of our study area, edaphic and topographic conditions seem to be the most important environmental drivers of species distribution (MEIRELES et al., 2008).

The altitudinal gradient and the anthropogenic disturbances resulted in high spatial heterogeneity in our study area, and together with natural disturbances were responsible for the punctual fluctuations in structure recorded here. Conservation and management measures must be taken to better know and host this diversity. In our specific case, the relevancy of the fragment is further highlighted by (1) its ecosystem service as a headwater maintainer, supplying the rivers in its region, (2) its occurrence in a significantly altered landscape and (3) the presence of threatened species such as the arborescent pteridophyte Dicksonia sellowiana Hook. (BRASIL, 2008).

\section{CONCLUSIONS}

The results point out to a forest characterized by the increase in plant density and basal area, mainly due to the continuous local anthropogenic disturbances observed in the area, such as the presence of cattle and trails. These disturbances start early successional processes in various sectors of the forest.

The altitudinal gradient leads to great environmental heterogeneity, resulting in a high species turnover, as well as high values of diversity which remained unchanged in the intervals considered.

\section{ACKNOWLEDGEMENTS}

This research was supported by $\mathrm{CNPq}$ (Edital Universal 2009, Processo 471688/2009-6) and FAPEMIG (Edital Universal 2008, APQ-00942-08).

\section{REFERENCES}

CARVALHO, F. A.; FELFILI, J. M. Variações temporais na comunidade arbórea de uma floresta decidual sobre afloramentos calcários no Brasil Central: composição, estrutura e diversidade florística. Acta Botanica Brasilica, v. 25 , n. 1 , p. 203-214, 2011. DOI: http://dx.doi.org/10.1590/S0102-33062011000100024

CHAZDON, R. L.; LETCHER, S. G.; VAN BREUGEL, M.; MARTÍNEZ-RAMOS, M.; BONGERS, F.; FINEGAN, B. Rates of change in tree communities of secondary Neotropical forests following major disturbances. Philosophical Transactions of the Royal Society B, v. 362 , n. $1478, \quad$ p. 273-289, 2007. DOI: http://dx.doi.org/10.1098/rstb.2006.1990

COLWELL, R. K. EstimateS: statistical estimation of species richness and shared species from samples. 2011. Avaliable from: http://viceroy.eeb.uconn.edu/estimates/ Access on: 3 set. 2015 .
GENTRY, A. H. Patterns of diversity and floristic composition in neotropical montane forests. In: Churchill, S. P. et al. (Eds.). Biodiversity and conservation of neotropical montane forests. New York: New York Botanical Garden, 1995. p. 103-126.

HIGUCHI, P.; OLIVEIRA-FILHO, A. T.; BEBBER, D. P.; BROWN, N. D.; SILVA, A. C.; MACHADO, E. L. M. Spatio-temporal patterns of tree community dynamics in a tropical forest fragment in South-east Brazil. Plant Ecology, v. 199, n. 1, p. 125- 135, 2008. DOI: http://dx.doi.org/10.1007/s11258-008-9418-x

JOLY, C. A.; METZGER, J. P.; TABARELLI, M. Experiences from the Brazilian Atlantic forest: ecological findings and conservation initiatives. New Phytologist, v. 204, n. 3, p. 459-473, 2014. DOI: http://dx.doi.org/10.1111/nph.12989

JUNTTILA, V., KAURANNE, T., FINLEY, A. O., BRADFORD, J. B. Linear models for airborne-laserscanning-based operational forest inventory with small field sample size and highly correlated LiDAR data. IEEE Trans. Geosci. Remote Sens., v. 53, p. 5600-5612, 2015. http://dx.doi.org/10.1109/TGRS.2015.2425916.

KENT, M.; COKER, P. Vegetation description and analysis, a practical approach. London: Belhaven Press, 1992. 363 p.

KORNING, J.; BALSLEV, H. Growth and mortality of trees in Amazonian tropical rain forest in Ecuador. Journal of Vegetation Science, v. 4, n. 1, p. 77-86, 1994. DOI: http://dx.doi.org/10.2307/3235641

LEVIN-NIELSEN, A.; RIESKE, L. K. Evaluating short term simulations of a forest stand invaded by emerald ash borer. iForest, v. 8 , p. 19-24, 2015. DOI: http://dx.doi.org/10.3832/ifor1163-007

MACHADO, E. L. M.; OLIVEIRA-FILHO, A. T. Spatial patterns of tree community dynamics are detectable in a small (4 ha) and disturbed fragment of the Brazilian Atlantic forest. Acta Botanica Brasilica, V. 24, n. 1, p. 250-261, 2010. DOI: http://dx.doi.org/10.1590/S010233062010000100027

MCCUNE, B.; MEFFORD, M. J. PC-ORD: multivariate analysis of ecological data. Version 5.10. MjM Software, Gleneden Beach, Oregon, USA. 2006.

MEIRELES, L. D.; SHEPHERD, G. J.; KINOSHITA, L. S. Variações na composição florística e na estrutura fitossociológica de uma floresta ombrófila densa altomontana na Serra da Mantiqueira, Monte Verde, MG. Revista Brasileira de Botânica, v. 31, n. 4, p. 559-574, 2008. DOI: http://dx.doi.org/10.1590/S010084042008000400003

MENEZES, M. D.; CURI, N.; MARQUES, J. J.; MELLO, C. R.; ARAÚJO, A. R. Levantamento pedológico e sistema de informações geográficas na avaliação do uso das terras em sub-bacia hidrográfica de Minas Gerais. Ciência e Agrotecnologia, v. 33, n. 6, p. 1544-1553, 2009. DOI: http://dx.doi.org/10.1590/S1413-70542009000600013

BRASIL. Ministério do Meio Ambiente. Instrução Normativa $\mathrm{n}^{\circ}$. 06, de 23 de Setembro de 2008. Lista Oficial da flora brasileira ameaçada de extinção. Diário Oficial da República Federativa do Brasil, Brasília, DF, n. 185, p. 7583, 24 set. 2008 . 
MUELller-DOMBOIS, D.; ELlENBERG, H. Aims and methods of vegetation ecology. New York: John Wiley \& Sons, 1974. $547 \mathrm{p}$.

NASCIMENTO, F. H. F.;GIULIETTI, A. M.; QUEIROZ, L. P. Diversidade arbórea das florestas alto montanas no Sul da Chapada Diamantina, Bahia, Brasil. Acta Botanica Brasilica, v. 24, n. 3, p. 674-685, 2010. DOI: http://dx.doi.org/10.1590/S0102-33062010000300011

OLIVEIRA-FILHO, A. T.; FONTES, M. A. L. Patterns of floristic differentiation among Atlantic Forests in Southeastern Brazil and the Influence of Climate. Biotropica, v. 32, n. 4b, p. 793-810, 2000. DOI: http://dx.doi.org/10.1111/j.1744-7429.2000.tb00619.x

OLIVEIRA-FILHO, A. T.; CARVALHO, W. A. C.; MACHADO, E. L. M.; HIGUCHI, P.; APPOLINÁRIO, V.; CASTRO, G. C.; SILVA, A. C.; SANTOS, R. M.; BORGES, L. F.; CORRÊA, B. S.; ALVES, J. A. Dinâmica da comunidade e populações arbóreas da borda e interior de um remanescente florestal na Serra da Mantiqueira, Minas Gerais, em um intervalo de cinco anos (1999-2004). Revista Brasileira de Botânica, v. 30, n. 1, p. 149-161, 2007. DOI: http://dx.doi.org/10.1590/S010084042007000100015

PEREIRA, I. M.; OLIVEIRA-FILHO, A. T.; BOTELHO, S. A.; CARVAlHO, W. A. C.; FONTES, M. A. L.; SCHIAVINI, I.; SILVA, A. F. Composição florística do compartimento arbóreo de cinco remanescentes florestais do maciço do Itatiaia, Minas Gerais e Rio de Janeiro. Rodriguésia, v. 57, n. 1, p. 103-126, 2006a.

PEREIRA, J. A. A.; OLIVEIRA-FILHO, A. T.; LEMOSFILHO, J. P. Environmental heterogeneity and disturbance by humans control much of the tree species diversity of Atlantic montane forest fragments in SE Brazil. Biodiversity and Conservation, v. 16, n. 6, p. 1761-1784, 2006b. DOI: http://dx.doi.org/10.1007/s10531-006-90634

PHILLIPS, O. L.; HIGUCHI, N.; VIEIRA, S.; BAKER, T. R.; CHAO, K.-J., LEWIS, S. L. Changes in Amazonian forest biomass, dynamics, and composition, 1980-2002. Geophysical Monograph Series, v. 186, p. 373-387, 2008. DOI: http://dx.doi.org/10.1029/2008GM000739

PHILLIPS, O. L.; BAKER, T. R. ; ARROYO, L.; HIGUCHI, N.; KILLEEN, T. J.; LAURANCE, W. F.; LEWIS, S. L.; LLOYD, J.; MALHI, Y.; MONTEAGUDO, A.; NEILL, D. A.; NÚÑEZ VARGAS, P.; SILVA, J. N. M.; TERBORGH, J.; VÁSQUEZ MARTÍNEZ, R; ALEXIADES, M.; ALMEIDA, S.; BROWN, S.; CHAVE, J.; COMISKEY, J. A.; CZIMCZIK, C. I.; DI FIORE, A.; ERWIN, T.; KUEBLER, C.; LAURANCE, S. G.; NASCIMENTO, H. E. M.; OLIVIER, J.; PALACIOS, W.; PATIÑO, S.; PITMAN, N. C. A.; QUESADA, C. A.; SALDIAS, M.; TORRES LEZAMA, A.; VINCETI B. Pattern and process in Amazon tree turnover, 1976-2001. Philosophical Transactions of The Royal Society B Biological Sciences, v. 359, n. 1443, p. 381-407, 2004. DOI: http://dx.doi.org/10.1098/rstb.2003.1438

PINTO, L. C.; MELLO, C. R.; ÁVILA, L. F. Water quality indicators in the Mantiqueira Range region, Minas Gerais state. CERNE, v. 19, n. 4, p. 687-692, 2013. DOI: http://dx.doi.org/10.1590/S0104-77602013000400020

POMPEU, P. V.; FONTES, M. A. L.; SANTOS, R. M.; GARCIA; P. O.; BATISTA, T. A.; CARVALHO, W. A. C.; OLIVEIRA-FILHO, A. T.. Floristic composition and structure of an upper montane cloud forest in the Serra da Mantiqueira Mountain Range of Brazil. Acta Botanica Brasilica, v. 28, n. 3, p. 456-464, 2014. DOI: http://dx.doi.org/10.1590/0102-33062014abb3239

RIBEIRO, M. C.; METZGER, J. P.; MARTENSEN, A. C.; PONZONI, F. J.; HIROTA, M. M. The Brazilian Atlantic Forest: How much is left, and how is the remaining forest distributed? Implications for conservation. Biological Conservation, v. 142, n. 6, p. 1141-1153, 2009. DOI: http://dx.doi.org/10.1016/j.biocon.2009.02.021

SCOLFORO, J. R. S.; OLIVEIRA, A. D.; ACERBI-JÚNIOR, F. W. Inventário florestal de Minas Gerais: equações de volume, peso de matéria seca e carbono para diferentes fisionomias da flora nativa. Lavras: UFLA, 2008. 169 p.

SHEIL, D.; MAY, R. M. Mortality and recruitment rate evaluations in heterogeneous tropical forests. Journal of Ecology, v. 84, n. 1, p. 91-100, 1996. DOI: http://dx.doi.org/10.2307/2261703

SHEIL, D.; BURSLEM, D. F. R. P.; ALDER, D. The Interpretation and misinterpretation of mortality rate measures. Journal of Ecology, v. 83, n. 2, p. 331-333, 1995. DOI: http://dx.doi.org/10.2307/2261571

SHEIL, D.; JENNINGS, S.; SAVILL, P. Long-term permanent plot observations of vegetation dynamics in Budongo, a Ugandan rain forest. Journal of Tropical Ecology, v. 16, n. 6, p. 765-800, 2000. DOI: http://dx.doi.org/10.1017/S0266467400001723

TABARELLI, M.; AGUIAR, A. V.; RIBEIRO, M. C.; METZGER, J. P.; PERES, C. P. Prospects for biodiversity conservation in the Atlantic Forest: Lessons from aging human-modified landscapes. Biological Conservation, v. 143 , n. $10, \quad$ p. 2328-2340, 2010. DOI: http://dx.doi.org/10.1016/j.biocon.2010.02.005

VALENTE, A. S. M.; GARCIA, P. O.; SALIMENA, F. R. G.; OLIVEIRA-FILHO, A. T. Composição, estrutura e similaridade florística da Floresta Atlântica, na Serra Negra, Rio Preto, MG. Rodriguésia, v. 62, n. 2, p. 321340, 2011. DOI: http://dx.doi.org/10.1590/21757860201162209

ZAR, J. H. Biostatistical analysis. Englewood Cliffs, NJ: Prentice Hall, 1984. 718 p. 
Table 2. Basal area (BA) and importance value (IV) of the tree species found in of three forest inventories $(2009,2011$ and 2012$)$ of the Atlantic Ombrophilous forest remnant in Bocaina de Minas, Minas Gerais state, Brazil, and the number of deaths (M) and recruits (R) for each species.

Tabela 2. Area basal (BA) e valor de importância (IV) das espécies arbóreas encontradas nos três inventários florestais (2009, 2011 e 2012) do remanescente de floresta Ombrófila Atlântica em Bocaina de Minas, Minas Gerais, Brasil, e o número de árvores mortas (M) e recrutas (R) para cada espécie.

\begin{tabular}{|c|c|c|c|c|c|c|c|c|c|c|c|c|c|}
\hline \multirow[b]{2}{*}{ Family } & \multirow[b]{2}{*}{ Species } & \multicolumn{2}{|c|}{2009} & \multicolumn{2}{|c|}{2011} & \multicolumn{2}{|c|}{2012} & \multicolumn{3}{|c|}{2011} & \multicolumn{3}{|c|}{2012} \\
\hline & & $\mathrm{BA}$ & IV & $\mathrm{BA}$ & IV & $\mathrm{BA}$ & IV & $\mathrm{D}$ & $\mathrm{R}$ & $\begin{array}{l}\text { IV } \\
\text { (P) }\end{array}$ & $\mathrm{D}$ & $\mathrm{R}$ & $\begin{array}{l}\text { IV } \\
\text { (P) }\end{array}$ \\
\hline Cunoniaceae & Lamanonia ternata Vell. & 3.68 & 25 & 3.68 & 23.7 & 3.81 & 23.9 & & 1 & 1 & & 3 & 1 \\
\hline Rubiaceae & Psychotria vellosiana Benth. & 0.96 & 18 & 0.96 & 16.8 & 0.99 & 16.7 & & 3 & 3 & 4 & 4 & 3 \\
\hline Primulaceae & Myrsine umbellata Mart. & 1.45 & 17 & 1.45 & 17.5 & 1.5 & 17.4 & & 7 & 2 & 1 & 1 & 2 \\
\hline Myrtaceae & Myrcia splendens (Sw.) DC. & 0.91 & 13 & 0.91 & 12.7 & 0.94 & 12.5 & & 2 & 5 & 2 & 1 & 5 \\
\hline Clethraceae & Clethra scabra Pers. & 0.81 & 13 & 0.81 & 13 & 0.89 & 13.3 & 1 & 7 & 4 & 1 & 3 & 4 \\
\hline Nyctaginaceae & Guapira opposita (Vell.) Reitz & 1.49 & 12 & 1.49 & 12 & 1.49 & 11.7 & & 2 & 6 & & & 6 \\
\hline Melastomataceae & Miconia sellowiana Naudin & 0.7 & 11 & 0.7 & 11 & 0.78 & 11 & 1 & 3 & 7 & 1 & & 7 \\
\hline Fabaceae & Inga sessilis (Vell.) Mart. & 0.75 & 9.9 & 0.75 & 9.75 & 0.8 & 9.77 & & 2 & 8 & & & 8 \\
\hline Euphorbiaceae & Alchornea triplinervia (Spreng.) Müll. Arg. & 1.03 & 9.6 & 1.03 & 9.66 & 1 & 9.45 & & 2 & 9 & & 1 & 9 \\
\hline Melastomataceae & Miconia cinerascens Miq. & 0.74 & 8.3 & 0.74 & 8.03 & 0.76 & 7.8 & 1 & & 10 & 2 & & 10 \\
\hline Asteraceae & Eremanthus erythropappus (DC.) MacLeish & 0.73 & 7.9 & 0.73 & 7.78 & 0.76 & 7.64 & & & 11 & 1 & & 11 \\
\hline Primulaceae & Myrsine coriacea (Sw.) R. Br. ex Roem. \& Schult. & 0.27 & 6.1 & 0.27 & 5.45 & 0.28 & 5.41 & 1 & & 14 & & & 14 \\
\hline Asteraceae & Baccharis serrulata (Lam.) Pers. & 0.72 & 5.9 & 0.72 & 5.78 & 0.61 & 5.12 & & & 17 & 2 & & 17 \\
\hline Melastomataceae & Tibouchina estrellensis (Raddi) Cogn. & 0.45 & 5.6 & 0.45 & 5.96 & 0.48 & 5.98 & & 1 & 13 & & & 15 \\
\hline Melastomataceae & Miconia latecrenata (DC.) Naudin & 0.56 & 5.5 & 0.56 & 5.43 & 0.62 & 5.75 & 1 & & 18 & & 2 & 18 \\
\hline Salicaceae & Casearia obliqua Spreng. & 0.69 & 5.1 & 0.69 & 4.94 & 0.72 & 4.95 & & & 12 & & & 12 \\
\hline Sapindaceae & Cupania paniculata Cambess. & 0.4 & 4.8 & 0.4 & 5.79 & 0.42 & 5.98 & & 2 & 15 & & 2 & 13 \\
\hline Dicksoniaceae & Dicksonia sellowiana Hook. & 0.66 & 4.7 & 0.66 & 5.53 & 0.68 & 5.48 & & 3 & 16 & & & 16 \\
\hline Melastomataceae & Miconia castaneiflora Naudin & 0.34 & 4.3 & 0.34 & 3.8 & 0.35 & 3.87 & & & 19 & & 1 & 19 \\
\hline Melastomataceae & Leandra quinquedentata (DC.) Cogn. & 0.25 & 3.5 & 0.25 & 3.44 & 0.26 & 3.76 & & 1 & 20 & 1 & 1 & 20 \\
\hline Salicaceae & Casearia mariquitensis Kunth & 0.24 & 3.4 & 0.24 & 3.42 & 0.28 & 3.51 & & 2 & 21 & & & 21 \\
\hline Solanaceae & Solanum bullatum Vell. & 0.34 & 3.4 & 0.34 & 3.23 & 0.32 & 3.01 & & & 23 & 1 & & 23 \\
\hline Melastomataceae & Miconia pusilliflora (DC.) Naudin & 0.2 & 3.4 & 0.2 & 3.35 & 0.2 & 3.33 & 1 & 2 & 22 & 1 & 1 & 25 \\
\hline Annonaceae & Annona cacans Warm. & 0.12 & 3.2 & 0.12 & 3.03 & 0.12 & 3.01 & & & 24 & & & 26 \\
\hline Euphorbiaceae & Pera glabrata (Schott) Poepp. ex Baill. & 0.29 & 3 & 0.29 & 2.92 & 0.3 & 3.33 & & & 26 & & 1 & 24 \\
\hline Melastomataceae & Miconia chartacea Triana & 0.16 & 2.9 & 0.16 & 2.94 & 0.17 & 3.06 & & 1 & 25 & & 1 & 22 \\
\hline Sapindaceae & Toulicia laevigata Radlk. & 0.32 & 2.8 & 0.32 & 2.7 & 0.33 & 2.68 & & & 27 & & & 29 \\
\hline Melastomataceae & Miconia trianae Cogn. & 0.22 & 2.7 & 0.22 & 2.62 & 0.24 & 2.53 & & & 33 & 1 & & 33 \\
\hline Apocynaceae & Aspidosperma spruceanum Benth. ex Müll. Arg. & 0.41 & 2.4 & 0.41 & 2.28 & 0.43 & 2.72 & & & 28 & & 1 & 27 \\
\hline Primulaceae & Cybianthus detergens Mart. & 0.24 & 2.4 & 0.24 & 2.56 & 0.24 & 2.52 & & & 31 & & & 28 \\
\hline Vochysiaceae & Vochysia magnifica Warm. & 0.21 & 2.3 & 0.21 & 2.61 & 0.2 & 2.07 & & 1 & 30 & 1 & & 30 \\
\hline Fabaceae & Tachigali rugosa (Mart. ex Benth.) Zarucchi \& Pipoly & 0.25 & 2.1 & 0.25 & 2.17 & 0.27 & 2.2 & & & 40 & & & 40 \\
\hline Bignoniaceae & Jacaranda subalpina Morawetz & 0.12 & 2.1 & 0.12 & 2.69 & 0.13 & 2.7 & & 2 & 29 & & & 32 \\
\hline Moraceae & Sorocea guilleminiana Gaudich. & 0.11 & 2.1 & 0.11 & 2.03 & 0.12 & 2.05 & & & 32 & & & 31 \\
\hline Lauraceae & Ocotea corymbosa (Meisn.) Mez & 0.29 & 2.1 & 0.29 & 1.99 & 0.3 & 1.98 & & & 34 & & & 34 \\
\hline Meliaceae & Cabralea canjerana (Vell.) Mart. & 0.14 & 2.1 & 0.14 & 1.98 & 0.15 & 1.97 & & & 49 & & & 39 \\
\hline Solanaceae & Solanum aturense Dunal & 0.11 & 2.1 & 0.11 & 1.97 & 0.11 & 1.94 & & & 39 & & & 49 \\
\hline Rubiaceae & Amaioua guianensis Aubl. & 0.06 & 2.1 & 0.06 & 1.98 & 0.06 & 1.96 & & & 35 & & & 35 \\
\hline Sapindaceae & Toulicia subsquamulata Radlk. & 0.13 & 1.9 & 0.13 & 2.01 & 0.14 & 2.02 & & 1 & 38 & & & 36 \\
\hline Chloranthaceae & Hedyosmum brasiliense Miq. & 0.1 & 1.9 & 0.1 & 2.37 & 0.12 & 2.5 & & 4 & 36 & & 1 & 38 \\
\hline Asteraceae & Piptocarpha axillaris (Less.) Baker & 0.08 & 1.9 & 0.08 & 1.82 & 0.09 & 1.83 & & & 37 & & & 37 \\
\hline Lauraceae & Aniba firmula (Nees \& Mart.) Mez & 0.09 & 1.9 & 0.09 & 1.78 & 0.11 & 1.81 & & & 41 & & & 41 \\
\hline Lauraceae & Cinnamomum glaziovii (Mez) Kosterm. & 0.33 & 1.8 & 0.33 & 1.77 & 0.33 & 1.7 & & & 42 & & & 42 \\
\hline Asteraceae & Piptocarpha macropoda (DC.) Baker & 0.14 & 1.8 & 0.14 & 1.72 & 0.15 & 1.71 & & & 43 & & & 44 \\
\hline Primulaceae & Myrsine gardneriana A. DC. & 0.1 & 1.8 & 0.1 & 1.67 & 0.1 & 1.65 & & & 44 & & & 43 \\
\hline Anacardiaceae & Tapirira obtusa (Benth.) J.D. Mitch. & 0.04 & 1.7 & 0.04 & 1.65 & 0.04 & 1.66 & & & 45 & & & 46 \\
\hline Aquifoliaceae & Ilex theizans Mart. ex Reissek & 0.09 & 1.7 & 0.09 & 1.59 & 0.09 & 1.58 & & & 46 & & & 45 \\
\hline Rubiaceae & Bathysa australis (A. St.-Hil.) Hook. f. ex K. Schum. & 0.11 & 1.7 & 0.11 & 1.61 & 0.12 & 1.6 & & & 48 & & & 48 \\
\hline Lamiaceae & Aegiphila verticillata Vell. & 0.04 & 1.6 & 0.04 & 2.02 & 0.05 & 2.01 & & 1 & 47 & & & 52 \\
\hline Rosaceae & Prunus myrtifolia (L.) Urb. & 0.12 & 1.6 & 0.12 & 1.56 & 0.13 & 1.55 & & & 51 & & & 47 \\
\hline Annonaceae & Guatteria australis A. St.-Hil. & 0.04 & 1.6 & 0.04 & 1.58 & 0.05 & 1.58 & & & 52 & & & 51 \\
\hline Lauraceae & Ocotea diospyrifolia (Meisn.) Mez & 0.07 & 1.6 & 0.07 & 1.58 & 0.08 & 1.59 & & & 50 & & & 50 \\
\hline Monimiaceae & Mollinedia lanceolata Ruiz \& Pav. & 0.05 & 1.4 & 0.05 & 1.36 & 0.05 & 1.34 & & & 72 & & & 55 \\
\hline Myrtaceae & Myrcia guianensis (Aubl.) DC. & 0.07 & 1.4 & 0.07 & 1.38 & 0.07 & 1.37 & & & 55 & & & 63 \\
\hline Lauraceae & Aniba canelilla (Kunth) Mez & 0.08 & 1.4 & 0.08 & 1.38 & 0.09 & 1.49 & & & 54 & & 1 & 54 \\
\hline Annonaceae & Guatteria pogonopus Mart. & 0.12 & 1.4 & 0.12 & 1.31 & 0.13 & 1.31 & & & 53 & & & 53 \\
\hline Fabaceae & Machaerium villosum Vogel & 0.05 & 1.3 & 0.05 & 1.25 & 0.05 & 1.26 & & & 56 & & & 56 \\
\hline Phytolaccaceae & Seguieria langsdorffii Moq. & 0.15 & 1.3 & 0.15 & 1.22 & 0.15 & 1.22 & & & 57 & & & 57 \\
\hline
\end{tabular}




\begin{tabular}{|c|c|c|c|c|c|c|c|c|c|c|c|c|c|}
\hline \multirow[b]{2}{*}{ Family } & \multirow[b]{2}{*}{ Species } & \multicolumn{2}{|c|}{2009} & \multicolumn{2}{|c|}{2011} & \multicolumn{2}{|c|}{2012} & \multicolumn{3}{|c|}{2011} & \multicolumn{3}{|c|}{2012} \\
\hline & & $\mathrm{BA}$ & IV & BA & IV & BA & IV & $\mathrm{D}$ & $\mathrm{R}$ & $\begin{array}{l}\text { IV } \\
\text { (P) }\end{array}$ & $\mathrm{D}$ & $\mathrm{R}$ & $\begin{array}{l}\text { IV } \\
\text { (P) }\end{array}$ \\
\hline Bignoniaceae & Jacaranda puberula Cham. & 0.02 & 1.2 & 0.02 & 1.16 & 0.03 & 1.15 & & & 58 & & & 58 \\
\hline Lauraceae & Ocotea pulchella (Nees \& Mart.) Mez & 0.13 & 1.2 & 0.13 & 1.15 & 0.14 & 1.15 & & & 59 & & & 62 \\
\hline Solanaceae & Solanum leucodendron Sendtn. & 0.04 & 1.2 & 0.04 & 1.11 & 0.03 & 1.07 & & & 60 & & & 59 \\
\hline Apocynaceae & Aspidosperma parvifolium A. DC. & 0.05 & 1.1 & 0.05 & 1.07 & 0.06 & 1.18 & & & 61 & & 1 & 60 \\
\hline Clusiaceae & Tovomita paniculata (Spreng.) Cambess. & 0.02 & 1.1 & 0.02 & 1.05 & 0.02 & 1.49 & & & 62 & & 1 & 61 \\
\hline Proteaceae & Euplassa rufa (Loes.) Sleumer & 0.14 & 1 & 0.14 & 1 & 0.14 & 0.96 & & & 63 & & & 66 \\
\hline Lauraceae & Cryptocarya aschersoniana $\mathrm{Mez}$ & 0.07 & 1 & 0.07 & 0.99 & 0.07 & 0.99 & & & 66 & & & 65 \\
\hline Euphorbiaceae & Alchornea glandulosa Poepp. & 0.03 & 1 & 0.03 & 1.01 & 0.04 & 1.01 & & & 64 & & & 87 \\
\hline Aquifoliaceae & Ilex paraguariensis A. St.-Hil. & 0.13 & 1 & 0.13 & 0.96 & 0.13 & 0.95 & & & 65 & & & 64 \\
\hline Myrtaceae & Siphoneugena densiflora O. Berg & 0.02 & 1 & 0.02 & 0.96 & 0.02 & 0.95 & & & 67 & & & 67 \\
\hline Sapindaceae & Cupania racemosa (Vell.) Radlk. & 0.01 & 1 & 0.01 & 0.92 & 0.01 & 0.91 & & & 68 & & & 68 \\
\hline Hypericaceae & Vismia guianensis (Aubl.) Pers. & 0.05 & 1 & 0.05 & 0.92 & 0.05 & 0.91 & & & 70 & & & 70 \\
\hline Annonaceae & Unonopsis guatterioides (A. DC.) R.E. Fr. & 0.01 & 1 & 0.01 & 0.91 & 0.01 & 0.9 & & & 69 & & & 69 \\
\hline Monimiaceae & Macropeplus dentatus (Perkins) I. Santos \& Peixoto & 0.11 & 0.9 & 0.11 & 1.4 & 0.09 & 0.88 & & 1 & 71 & 1 & & 71 \\
\hline Celastraceae & Maytenus glazioviana Loes. ex Taub. & 0.06 & 0.8 & 0.06 & 0.78 & 0.07 & 0.78 & & & 75 & & & 72 \\
\hline Boraginaceae & Cordia magnoliifolia Cham. & 0.05 & 0.8 & 0.05 & 0.72 & 0.05 & 0.7 & & & 73 & & & 75 \\
\hline Clusiaceae & Clusia grandiflora Splitg. & 0.04 & 0.8 & 0.04 & 0.79 & 0.05 & 0.81 & & & 76 & & & 73 \\
\hline Lamiaceae & Hyptidendron asperrimum (Epling) Harley & 0.06 & 0.8 & 0.06 & 0.77 & 0.06 & 0.78 & & & 77 & & & 76 \\
\hline Melastomataceae & Miconia cinnamomifolia (DC.) Naudin & 0.07 & 0.8 & 0.07 & 0.72 & 0.07 & 0.72 & & & 74 & & & 77 \\
\hline Fabaceae & Leucochloron incuriale (Vell.) Barneby \& J.W. Grimes & 0.04 & 0.7 & 0.04 & 0.67 & 0.04 & 0.67 & & & 79 & & & 74 \\
\hline Asteraceae & Dasyphyllum brasiliense (Spreng.) Cabrera & 0.04 & 0.7 & 0.04 & 0.68 & 0.04 & 0.69 & & & 78 & & & 79 \\
\hline Annonaceae & Annona sylvatica A. St.-Hil. & 0.02 & 0.6 & 0.02 & 0.62 & 0.02 & 0.62 & & & 80 & & & 78 \\
\hline Melastomataceae & Tibouchina Aubl. sp. & 0.04 & 0.6 & 0.04 & 0.59 & 0.04 & 0.58 & & & 82 & & & 80 \\
\hline Thymelaeaceae & Daphnopsis utilis Warm. & 0.04 & 0.6 & 0.04 & 0.6 & 0.04 & 0.59 & & & 81 & & & 82 \\
\hline Fabaceae & Inga thibaudiana DC. & 0.01 & 0.6 & 0.01 & 0.58 & 0.01 & 0.57 & & & 95 & & & 81 \\
\hline Urticaceae & Boehmeria caudata $\mathrm{Sw}$. & 0.03 & 0.6 & 0.03 & 0.57 & 0.03 & 0.56 & & & 83 & & & 95 \\
\hline Symplocaceae & Symplocos celastrinea Mart. ex Miq. & 0.03 & 0.6 & 0.03 & 0.55 & 0.03 & 0.54 & & & 84 & & & 83 \\
\hline Sapindaceae & Allophylus petiolulatus Radlk. & 0.02 & 0.5 & 0.02 & 0.51 & 0.02 & 0.51 & & & 85 & & & 84 \\
\hline Phyllanthaceae & Hieronyma alchorneoides Allemão & 0.02 & 0.5 & 0.02 & 0.52 & 0.03 & 0.97 & & & 90 & & 1 & 85 \\
\hline Rubiaceae & Psychotria suterella Müll. Arg. & 0.02 & 0.5 & 0.02 & 0.51 & 0.02 & 0.51 & & & 87 & & & 90 \\
\hline Asteraceae & Baccharis rufidula (Spreng.) Joch. Müll. & 0.02 & 0.5 & 0.02 & 0.5 & 0.02 & 0.5 & & & 86 & & & 88 \\
\hline Asteraceae & Vernonanthura divaricata (Spreng.) H. Rob. & 0.02 & 0.5 & 0.02 & 0.52 & 0.02 & 0.53 & & & 88 & & & 86 \\
\hline Melastomataceae & Tibouchina granulosa (Desr.) Cogn. & 0.01 & 0.5 & 0.01 & 0.49 & 0.01 & 0.48 & & & 89 & & & 89 \\
\hline Myrtaceae & Calyptranthes widgreniana $\mathrm{O}$. Berg & 0.01 & 0.5 & 0.01 & 0.48 & 0.01 & 0.47 & & & 91 & & & 91 \\
\hline Annonaceae & Guatteria villosissima A. St.-Hil. & 0.01 & 0.5 & 0.01 & 0.48 & 0.01 & 0.48 & & & 93 & & & 93 \\
\hline Vochysiaceae & Qualea dichotoma (Mart.) Warm. & 0.01 & 0.5 & 0.01 & 0.47 & 0.01 & 0.46 & & & 92 & & & 92 \\
\hline Salicaceae & Casearia decandra Jacq. & 0.01 & 0.5 & 0.01 & 0.58 & 0.01 & 0.58 & & 1 & 96 & & & 104 \\
\hline Celastraceae & Maytenus robusta Reissek & 0.01 & 0.5 & 0.01 & 0.47 & 0.01 & 0.46 & & & 94 & & & 96 \\
\hline Melastomataceae & Leandra Raddi sp. & 0.01 & 0.5 & 0.01 & 0.47 & 0.01 & 0.46 & & & 97 & & & 94 \\
\hline Lauraceae & Cryptocarya moschata Nees \& Mart. & 0 & 0.5 & 0 & 0.46 & 0.01 & 0.45 & & & 104 & & & 102 \\
\hline Myrtaceae & Myrceugenia miersiana (Gardner) D. Legrand \& Kausel & 0.01 & 0.5 & 0.01 & 0.46 & 0 & 0.45 & & & 99 & & & 97 \\
\hline Celastraceae & Maytenus salicifolia Reissek & 0.01 & 0.5 & 0.01 & 0.46 & 0.01 & 0.45 & & & 102 & & & 103 \\
\hline Myrtaceae & Myrcia obovata (O. Berg) Nied. & 0 & 0.5 & 0 & 0.46 & 0 & 0.45 & & & 100 & & & 105 \\
\hline Apocynaceae & Aspidosperma olivaceum Müll. Arg. & 0.01 & 0 & 0.01 & 0.46 & 0.01 & 0.46 & & 1 & 105 & & & 100 \\
\hline Asteraceae & Baccharis brachylaenoides DC. & 0 & 0 & 0 & 0.46 & 0.01 & 0.46 & & 1 & 98 & & & 98 \\
\hline Symplocaceae & Symplocos insignis Brade.A. & 0.01 & 0 & 0.01 & 0.46 & 0.01 & 0.47 & & 1 & 101 & & & 99 \\
\hline Clusiaceae & Tovomitopsis saldanhae Engl. & 0 & 0 & 0 & 0.46 & 0.01 & 0.46 & & 1 & 103 & & & 101 \\
\hline Total & & 24.98 & 300 & 24.98 & 300 & 25.8 & 300 & 6 & 56 & & 20 & 28 & \\
\hline
\end{tabular}

